\title{
HUBUNGAN ASUPAN MINERAL TERHADAP KARIES GIGI PADA SISWA-SISWI KELAS IV SD SWASTA MUHAMMADIYAH 03 KELURAHAN TANJUNG REJO KECAMATAN MEDAN SELAYANG
}

\author{
Intan Aritonang ${ }^{1}$, Yetti Lusiani ${ }^{2}$, Hasny $^{3}$ \\ Politeknik Kesehatan Kemenkes Medan, Jurusan Keperawatan Gigi
}

\begin{abstract}
Dental and oral health is part of physical health which cannot be separated from one another and it can affect for all people. The target of increasing dental and mouth health through group counseling activity is elementary school children since this age is social transition period when children change their behavior.The research was an analytical survey which was aim to find out the correlation between mineral intake and dental caries in Grade IV elementary students at SD Swasta Muhammnadiyah 03, Medan Selayang.This research was conducted by using subjective and objective examination on 33 students. The result of subjective examination showed intake of Mineral Nutrision performed, 8 respondents (24.24\%) had good intake, 18 respondents (54.55\%) had moderate intake, and 7 respondents $(21.21 \%)$ had bad intake. The conclusion of the research that there is a significant relationship between the intake of minerals with dental caries student of $S D$ Muhammadiyah 03, $p$ worth of 0.035 for $\alpha=0.05$. To reduce the increase in the incidence of caries is increase oral hygiene, better mineral intake and perform curative action by doing fillings for Grade IV students of SD Swasta Muhammadiyah 03 Medan Selayang.
\end{abstract}

Keywords : Counseling, Knowledge, Dental Caries Examination

\section{PENDAHULUAN}

Pembangunan sektor kesehatan nasional diarahkan untuk meningkatkan derajat kesehatan masyarakat yang optimal, meningkatkan gizi, membudayakan sikap hidup bersih dan sehat serta meningkatkan mutu dan mempermudahkan pelayanan kesehatan yang harus terjangkau oleh seluruh masyarakat.Arahan ini mencakup bidang kesehatan gigi dan mulut bahwa upaya kesehatan gigi dan mulut dilaksanakan dengan memacu meningkatkan kemandirian masyarakat untuk menolong dirinya sendiri dalam memelihara kesehatan gigi. Hal ini diupayakan melalui usaha-usaha promotif, preventif dan kuratif (Depkes RI, 2000)..

Asupan mineral dan vitamin pada orang yang telah mengalami kehilangan gigi atau memiliki jumlah gigi yang sedikit disebabkan menurunnya kemampuan pengunyahan. Seseorang yang kehilangan gigi pada bagian posterior dan memiliki jumlah gigi yang sedikit cenderung memilih makanan yang lebih mudah dikunyah. Makanan adalah bahan selain obat yang mengandung zat-zat nutrisi dan atau unsur/ikatan kimia yang dapat diubah menjadi nutrisi oleh tubuh, yang berguna bila dimasukkan kedalam tubuh. Nutrisi adalah ikatan kimia yang diperlukan tubuh untuk melakukan fungsinya, yaitu menghasilkan energi, membangun, dan memelihara jaringan, serta mengatur proses kehidupan. Konsumsi makanan berpengaruh terhadap status nutrisi seseorang.Nutrisi yang baik atau nutrisi yang optimal terjadi bila tubuh memperoleh cukup zat-zat nutrisi yang digunakan secara efisien, sehingga memungkinkan pertumbuhan fisik, perkembangan otak, kemampuan kerja dan kesehatan secara umum.Status nutrisi yang kurang optimal terjadi bila tubuh mengalami kekurangan satu atau lebih zat-zat essensial. Zat nutrisi terdiri dari karbohidrat, protein, lemak, vitamin, dan mineral.Pemenuhan kebutuhan nutrisi yang tidak seimbang menyebabkan dampak bagi tubuh secara umum, seperti terjadinya penyakit sistemik, penurunan kemampuan fungsional serta peningkatan infeksi sehingga mempengaruhi kualitas hidup masyarakat (Yoshihara dkk, 2013).

Perkembangan karies gigi hampir serupa.Mula-mula, lokasi terjadinya karies dapat tampak seperti daerah berkapur namun berkembang menjadi lubang gigi disebabkan oleh beberapa tipe dari bakteri penghasil asam yang dapat merusak karena reaksi fermentasi karbohidrat termasuk sukrosa, fruktosa, dan glukosa. Asam yang di produksi tersebut mempengaruhi mineral gigi sehingga $\mathrm{pH}$ turun menjadi di bawah 5,5, proses demineralisasi menjadi cepat dari reminalisasi. Hal ini menyebabkan lebih banyak mineral gigi yang terurai dan membuat lubang pada gigi.(Dewi Indra dan Yetik Wulandari, 2013).

Kerusakan jaringan yang di mulai dari (fit, fisur, dan daerah inter proksimal) meluas kearah pulpa (Brauer). Karies gigi di sebut juga dengan lubang gigi merupakan suatu penyakit dimana bakteri merusak sistem jaringan gigi 
(email, dentin) sehingga menyebabkan gigi berlubang. (Rasinta, 2013)

Berdasarkan uraian diatas peneliti tertarik untuk mengetahui "Hubungan Asupan Mineral Terhadap Karies Gigi Pada siswa-siswi Kelas IV SD Swasta Muhammadiyah 03 Kelurahan Tanjung Rejo Kecamatan Medan Selayang Tahun 2016.

\section{Tujuan Penelitian}

Untuk mengetahui Hubungan Asupan Mineral Terhadap Karies Gigi Pada siswa-siswi Kelas IV SD Swasta Muhammadiyah 03 Kelurahan Tanjung Rejo Kecamatan Medan Selayang Tahun 2016.

\section{Manfaat Penelitian}

1. Meningkatkan pengetahuan siswa-siswi Kelas IV SD Swasta Muhammadiyah 03 Kelurahan Tanjung Rejo Kecamatan Medan Selayang, tentang Hubungan Asupan Mineral Terhadap Keadaan Karies.

2. Informasi dan bahan masukan bagi pihak sekolah agar program UKGS dapat dilaksanakan yang terintegrasi dalam UKS.

3. Sebagai bahan masukan bagi peneliti lain dan sebagai bahan referensi di perpustakaan Jurusan Kesehatan Gigi Politeknik Kesehatan Kemenkes Medan.

4. Kepada pihak sekolah melalui program UKS dapat memberikan informasi tentang Asupan Mineral terhadap Karies Gigi untuk pemeliharaan kesehatan gigi dan mulut.

\section{METODE PENELITIAN}

\section{Jenis dan Desain Penelitian}

Jenis penelitian ini bersifat analitik dengan desain penelitian cross sectional dengan sampel 33 siswa yang diperoleh dari kuesioner dan pemeriksaan langsung. Untuk mengetahui Hubungan Asupan Mineral Terhadap Karies Gigi pada Siswa-siswi Kelas IV SD Swasta Muhammadiyah 03 Kelurahan Tanjung rejo Kecamatan Medan Selayang dengan uji one way anova.

\section{Populasi dan Sampel Penelitian}

Populasi adalah keseluruhan objek penelitian atau seluruh objek yang akan diteliti oleh peneliti (Soekijo, 2005). Populasi yang dilakukan dalam penelitian ini adalah seluruh Hubungan Asupan Mineral Terhadap Karies Gigi Pada siswa-siswi Kelas IV SD Swasta Muhammadiyah 03 Kelurahan Tanjung Rejo Kecamatan Medan Selayang Tahun 2016 yang berjumlah 200 orang.

Sampel adalah sebagian dari jumlah populasi yang diteliti (Arikunto, 2002).Jika jumlah populasi lebih besar dari (>100), sampel dapat diambil antara 10-15\% atau 20\%-25\% atau lebih. Akan tetapi jika jumlah populasi kurang $(<100)$, dapat diambil semua. Peneliti hanya mengambil sampel minimal dari 200 populasi yaitu 33 orang, peneliti menentukan pada kelas IV dengan alasan proses belajar mengajar di kelas lain tidak terganggu.

\section{HASIL DAN PEMBAHASAN}

\section{Hasil Penelitian}

Berdasarkan dari hasil penelitian yang dilakukan Hubungan Asupan Mineral Terhadap Karies Gigi Pada siswa-siswi Kelas IV SD Swasta Muhammadiyah 03 Kelurahan Tanjung Rejo Kecamatan Medan Selayang yang diperoleh dengan cara pemeriksan langsung pada sampel yang berjumlah 33 orang. Setelah seluruh data terkumpul, maka dilakukan analisa data dengan membuat tabel distribusi frekuensi sebagai berikut :

Tabel 1 DistribusiFrekuensi berdasarkan jenis kelamin Hubungan Asupan Mineral Terhadap Karies Gigi Pada siswa-siswi Kelas IV SD Swasta Muhammadiyah 03 Kelurahan Tanjung Rejo Kecamatan Medan Selayang Tahun 2016.

\begin{tabular}{lll}
\hline Jenis Kelamin & $\mathbf{n}$ & \% \\
\hline Laki-laki & 14 & 42,42 \\
Perempuan & 19 & 57,58 \\
\hline Jumlah & $\mathbf{3 3}$ & $\mathbf{1 0 0 , 0 0}$ \\
\hline
\end{tabular}

Dari tabel diperoleh bahwa jumlah laki adalah 14 siswa $(42,42 \%)$ perempuan 19 siswa $(57,58 \%)$, dengan demikian bahwa jumlah perempuan lebih banyak dari jumlah laki-laki.

Tabel 2 Distribusi Frekuensi Berdasarkan Asupan Mineral pada siswa-siswi Kelas IVSD Swasta Muhammadiyah 03 Kelurahan Tanjung Rejo Kecamatan Medan Selayang Tahun 2016

\begin{tabular}{lcc}
\hline $\begin{array}{c}\text { Kriteria Asupan } \\
\text { Mineral }\end{array}$ & n & \% \\
\hline Baik & 8 & 24,24 \\
Sedang & 18 & 54,55 \\
Buruk & 7 & 21,21 \\
\hline Jumlah & $\mathbf{3 3}$ & $\mathbf{1 0 0 , 0 0}$ \\
\hline
\end{tabular}

Dari tabel di atas diperoleh bahwa jumlah siswa dengan Asupan Mineral pada siswa-siswi kelas IV SD Swasta Muhammadiyah 03 dengan kriteria baik adalah 8 $(24,24 \%)$, Kriteria Sedang 18 siswa $(54,55 \%)$, Kurang 7 siswa $(21,21 \%)$, dengan demikian bahwa jumlah siswa dengan Asupan Mineral yang terbesaradalah kriteria sedang sebanyak 18 siswa, kriteria baik sebanyak 8 siswa, dan kriteria kurang sebanyak 7 siswa.

Tabel 3 Rata-rata Jumlah Karies Gigi Siswa pada siswasiswi Kelas IV SD Swasta Muhammadiyah 03 Kelurahan Tanjung Rejo Kecamatan Medan Selayang Tahun 2016.

\begin{tabular}{llll}
\multicolumn{1}{c}{ Uraian } & $\mathrm{n}$ & Rata-rata & $\begin{array}{l}\text { Standar } \\
\text { Deviasi }\end{array}$ \\
\hline $\begin{array}{l}\text { Jumlah } \\
\text { Karies }\end{array}$ & 33 & 2,73 & 2,23 \\
\hline
\end{tabular}

Dari tabel diperoleh bahwa rata-rata karies pada siswa-siswi Kelas IV SD Swasta Muhammadiyah 03 Kelurahan Tanjung Rejo Kecamatan Medan Selayang 
Tahun 2015 adalah sebesar 2,73 yang berarti untuk setiap anak, dijumpai 2-3 gigi sudah terkena karies.

Tabel 4 Analisa Bivariat Uji Hubungan Asupan Mineral Terhadap Karies Anak pada siswa-siswi Kelas IV SD Swasta Muhammadiyah 03 Kelurahan Tanjung Rejo Kecamatan Medan Selayang Tahun 2016

\begin{tabular}{lllllll}
\hline $\begin{array}{c}\text { Kriteria } \\
\begin{array}{c}\text { Asupan } \\
\text { Mineral }\end{array}\end{array}$ & n & $\begin{array}{c}\text { Rata- } \\
\text { rata }\end{array}$ & SD & $\boldsymbol{p}$ & \multicolumn{2}{c}{$\begin{array}{c}\text { 95\% Confidence } \\
\text { interval for Mean }\end{array}$} \\
\hline Baik & 8 & 1.25 & 1.28 & & 0.18 & 2.32 \\
Sedang & 18 & 2.83 & 2.18 & 0,035 & 1.75 & 3.92 \\
Buruk & 7 & 4.14 & 2.41 & & 1.91 & 6.37 \\
\hline
\end{tabular}

Dari tabel diperoleh bahwa nilai $p$ untuk derajat kepercayaan $95 \% \quad(\alpha=0,05)$ adalah sebesar 0,035 atau kurang dari 0,05 , hal ini menunjukkan bahwa ada hubungan yang signifikan antara asupan mineral dengan karies gigi anak pada siswa-siswi Kelas IV SD Swasta Muhammadiyah 03 Kelurahan Tanjung Rejo Kecamatan Medan Selayang Tahun 2016.

\section{PEMBAHASAN}

Dari hasil penelitian yang dilakukan pada siswasiswi Kelas IV SD Swasta Muhammadiyah 03 Kelurahan Tanjung Rejo Kecamatan Medan Selayang Tahun 2015 tentang Hubungan asupan mineral terhadap karies gigi. Diperoleh bahwa asupan mineral kategori baik berjumlah 8 siswa $(24,24 \%)$, kategori sedang 18 siswa $(54,55 \%)$ dan kategori buruk 7 siswa $(21,21 \%)$ dengan demikian bahwa jumlah siswa dengan Asupan Mineral yang terbesar adalah kriteria sedang sebanyak 18 siswa, kriteria baik sebanyak 8 siswa, dan kriteria kurang sebanyak 7 siswa. Hal ini disebabkan karena masih ada siswa yang belum mengetahui pentingnya asupan mineral untuk tubuh.

Jadi secara umum tingkat Asupan mineral siswasiswii Kelas IV SD Swasta Muhammadiyah 03 Kelurahan Tanjung Rejo Kecamatan Medan Selayang Tahun 2015 adalah 78,79\% sedang dan baik, hal ini disebabkan oleh ketersedian pangan sebagai sumber gizi dan mineral sudah cukup, hal terbukti dari Penelitian Riskesdas (2007)

Nutrisi juga penting peranannya dalam setiap tahap tumbuh kembang gigi dan dalam menjaga keseimbangan lingkungan mulut yang dihubungkan dengan kesehatan gigi. Nutrisi untuk pertumbuhan optimal gigi sama dengan nutrisi yang diperlukan tubuh karena masa pertumbuhan gigi sejalan dengan masa pertumbuhan tubuh secara keseluruhan. Nutrisi penting untuk klasifikasi optimal gigi sulung, sedangkan nutrisi pada masa balita dan anak-anak penting untuk pertumbuhan gigi tetap.Meningkatnya masalah gizi, tentunya berdampak pula pada peningkatan prevalensi penyakit gigi dan mulut yang dapat mengakibatkan bertambah buruknya masalah gizi tersebut.Mengetahui hubungan antara status gizi dan kesehatan gigi dan mulut menjadi penting karena seringkali terdapat karakteristik yang khas dari berbagai jaringan dalam rongga mulut yang lebih sensitif terhadap defisiensi nutrisi, sehingga apabila tubuh mengalami defisiensi nutrisi seringkali jaringan dalam rongga mulut yang pertama kali memperlihatkan efek defisiensi nutrisi tersebut (Moyers, 1998).

Penderita Karies gigi adalah penyakit yang tersebar di seluruh dunia. Perkembangan karies gigi hampir serupa. Mula-mula,lokasi terjadinya karies dapat tampak seperti daerah berkapur namun berkembang menjadi lubang gigi disebabkan oleh beberapa tipe dari bakteri penghasil asam yang dapat merusak karena reaksi fermentasi karbohidrat termasuk sukrosa, fruktosa dan glukosa. Asam yang diproduksi tersebut mempengaruhi mineral gigi sehingga $\mathrm{pH}$ turun menjadi di bawah 5,5. Proses demineralisasi menjadi cepat dari reminalisasi. Hal ini menyebabkan lebih banyak mineral gigi yang terurai dan membuat lubang pada gigi. (Dewi Indra dan Yettik Wulandari, 2013).

Rata-rata karies pada siswa-siswi Kelas IV SD Swasta Muhammadiyah 03 adalah sebesar 2,73 yang berarti untuk setiap anak, dijumpai 2-3 gigi sudah terkena karies. Hal ini disebabkan siswa tersebut maupun orangtua kurang memperhatikan kesehatan giginya

Diperoleh bahwa nilai $p$ untuk derajat kepercayaan $95 \%(\alpha=0,05)$ adalah sebesar 0,035 atau kurang dari 0,05 , hal ini menunjukkan bahwa ada hubungan yang signifikan antara asupan mineral dengan keadaan karies gigi anak pada siswa-siswi Kelas IV SD Swasta Muhammadiyah 03

Tindakan yang dapat dilakukan untuk mengurangi peningkatan kejadian karies adalah peningkatan keadaan kebersihan gigi dan mulut, asupan mineral yang baik dan melakukan tindakan kuratif dengan melakukan tumpatan atau tambalan

\section{SIMPULAN}

1. Jumlah siswa-siswikelas IV SD Swasta Muhammadiyah 03 dengan Asupan mineral kriteria baik adalah 8 siswa $(24,24 \%)$, kriteria sedang 18 siswa $(54,55 \%)$, kriteria kurang 7 siswa $(21,21 \%)$, dengan demikian bahwa jumlah siswa dengan asupan mineral yang terbesar adalah kriteria sedang ada 18 siswa, baik 8 siswa, kurang 7 siswa.

2. Rata-rata jumlah karies gigi siswa-siswikelas IV SD Swasta Muhammadiyah 03 adalah sebesar 2,73 yang berarti untuk setiap anak, dijumpai 2-3 gigi sudah terkena karies.

3. Ada hubungan yang signifikan antara asupan mineral terhadap kariesgigi anakSD Swasta Muhammadiyah 03 dengan p senilai 0,035 untuk $\alpha=0,05$

\section{SARAN}

1. Bagi siswa-siswi ikelas IV SD Swasta Muhammadiyah diharapkan dapat memilih makanan yang dapat memenuhi asupan mineral dalam tubuh.

2. Bagi pihak sekolah dapat memberi arahan kepada pada siswa-siswi Kelas SD Swasta 
Muhammadiyah 03 agar mereka dapat memilih makanan yang dapat memenuhi kebutuhan Asupan Mineral mereka.

3. Bagi pihak pemerintah dapat memberi arahan mencakup bidang kesehatan gigi dan mulut bahwa upaya kesehatan gigi dan mulut dilaksanakan dengan memacu meningkatkan kemandirian masyarakat untuk menolong dirinya sendiri dalam memelihara kesehatan gigi. Hal ini diupayakan melalui usaha-usaha promotif, preventif dan kuratif (Depkes RI, 2000).

4. Bagi pihak Institusi Pendidikan Kesehatan Gigi dapat memberi penyuluhan tentang pentingnya asupan mineral terhadap kesehatan gigi kepada SD Swasta Muhammadiyah 03.

\section{DAFTAR PUSTAKA}

Arikunto, S, 2002, ProsedurPenelitian, RinekaCipta, Jakarta.

Dewi Indra dan Yettik Wulandari_Prinsip-Prinsip Dasar Ahli Gizi 2013 Jakarta.

G.V. Black, Karies diklasifikasikan menggunakan spesipikHerijuliantidkk, 2002, MasalahKesehatan Gigi di Indonesia.
Moyers, 1988, DefenisiNutrisi.

Politeknik Kesehatan, 2006, Pedoman Tata Laksana Karya Tulis Ilmiah, Medan.

PoliteknikKesehatan, 2009, Diktat Preventif Dentistry, Oral Hygiene Indeks, Medan.

Tarigan,Rasinta Karies gigi/ penulis,rasinta tarigan; editor, Lilian Juwono Ed.2- Jakarta: EGC,2013

Tarigan,R, 1990, Karies Gigi, Hipokrates, Jakarta.

www.karies.com (besford, 1996) diunduh tanggal 29 Juli 2015

www.karies.comkaries sebagai penyakit bakteria (Newburn dalam darwita 2004)diunduh tanggal 29 Juli 2015. 